\title{
The Consciousness and Human Knowledge of Christ According to Lonergan and Balthasar
}

\author{
Aaron Pidel, SJ \\ Boston College School of Theology and Ministry
}

Bernard Lonergan and Hans Urs von Balthasar both gave considerable attention to the consciousness and human knowledge of Christ. In their respective treatments of this topic, both theologians evince common tendencies. Both are at pains to develop a model of Christ's human consciousness that 1) avoids the impression of psychological dualism, 2) acknowledges Christ to be a unique comprehensor (beholder) of the divine nature, and yet 3) shows Christ to be a true viator (wayfarer), learning and discerning in a genuinely human fashion. Lonergan does this through his model of "ineffable knowledge," and Balthasar through "mission consciousness." On the face of it, they seem to disagree as to whether Christ possessed the so-called visio beata (beatific vision) —with Lonergan answering affirmatively and Balthasar answering negatively. Nonetheless, because they understand the meaning of this attribution differently, it seems likely they are divided more at the level of verbal formulation than at the level of conceptual judgment. Both consciousness Christologies prove convergent and complementary.

Aaron Pidel, S.J., just completed concurrently his third year of the M.Div. program and his second year of the S.T.L. program; starting in the Fall, he will serve as a priest at the Gesu Parish in Miami, FL. 


\section{Introduction}

This paper aims to explore the compatibility and complementarity of the thought of Bernard Lonergan, SJ, and Hans Urs von Balthasar regarding Christ's consciousness and human knowledge. Though the goal of any consciousness Christology is to provide a "rule" capable of unifying the complex portrait of Christ painted in Scripture, this paper will not engage in detailed exegesis. Instead, it will compare Lonergan and Balthasar on three general and presumed features of the Gospel portrait: that 1) Christ's orientation and obedience toward the Father were the outstanding features of Christ's religious psychology; 2) that Christ was a unique and perfect comprehensor, or "beholder," of God; and 3) that Christ was also a true viator, or "wayfarer," learning and discerning throughout the course of his earthly life. Along the way, this paper will give special attention to the aforesaid authors' understanding and evaluation of the traditional doctrine of the "beatific vision."1

This essay concludes that Lonergan and Balthasar hold convergent and complementary understandings of Christ's consciousness and knowledge on these points. This remains true despite their difference in theological style and their ostensibly contrasting positions on Christ's

\footnotetext{
${ }^{1}$ Though developed as a speculative position among the scholastics, official Church teaching deployed the language of "beatific vision" or "beatific knowledge" throughout the $20^{\text {th }}$ Century. The decree of the Holy Office of June 5 , 1918 declared that there existed in Christ while on earth "the knowledge that the blessed possess by vision" (DS 3645). Mystici Corporis (1943) taught that Christ, "through the beatific vision ... held all the members of the mystical body continually and perpetually present to Himself" (DS 3812). Haurietis Aquas (1956) affirms that Christ had both infused and "beatific" knowledge" (DS 3924). For a treatment of the doctrinal weight of the various affirmations, see J. Galot, SJ, Who is Christ?: A Theology of the Incarnation, trans. M. A. Bouchard (Rome: Gregorian University Press, 1980), 357, fn. 33.

In more recent times, the International Theological Commission published "The Consciousness of Christ Concerning Himself and His Mission" (1985), which was reprinted under the same title in Communio 14:3 (1987), 316-25. The ITC focused mostly on four foundational assertions: that Christ was conscious of his filial relationship with the Father, that he was aware of the saving purpose of his mission, that he envisioned and willed the foundation of the Church, and that he was aware that he died for all. The Congregation for the Doctrine of the Faith's Notification on the Works of Fr. Jon Sobrino SJ (2006) focused more on Sobrino's ascription of faith—without further qualification - to Christ. The CDF, referring to Mystici Corporis (inter alia), ruled that Christ's possession of the beatific vision excluded faith in the usual sense of the term: accessed May, 2010, http://www.vatican.va/roman_curia/congregations/cfaith/documents/rc_con_cfaith_doc_20061126_notificationsobrino_en.html.
} 
earthly possession of the visio beata. However, while differences do exist at the level of verbal formulation, I suggest that a deeper agreement abides at the level of theological judgment.

\section{Lonergan on the Consciousness of Christ}

Taking the definitions of Chalcedon as the point of departure for his speculations on Christ's consciousness, Lonergan draws a complex analogy between Christ's ontological constitution and his psychological constitution. ${ }^{2}$ Though nearly all theologians were likewise extrapolating from Chalcedon, Lonergan brought a more sophisticated phenomenology of consciousness to bear. Precise distinctions in this domain allowed Lonergan to articulate Christ's psychological unity without yielding to monophysitism. They also allowed him to affirm Christ's lifelong enjoyment of the visio beata without diluting his status as genuine viator in solidarity with humanity. Lonergan, nonetheless, successively redescribes the visio beata as scientia beata ${ }^{3}$ and scientia ineffabilis ${ }^{4}$ in order to highlight the true meaning of the doctrinal tradition and discourage docetic misinterpretations.

\section{Overcoming Psychological Dualism}

In order to understand the elegance of Lonergan's solution, one does well to review questions that confront anyone attempting to describe Christ's consciousness. How does Christ as man know that he is God? Would not Christ's human nature gaze from an infinite distance at his divine nature? Even granting that he could know that he was God, how could Christ as man

\footnotetext{
${ }^{2}$ Lonergan explains his approach: "One cannot accept 'eundemque perfectum in deitate, et eundem perfectum in humanitate' in an ontological sense to the exclusion of a psychological sense. The councils do not make any such reservation. On the contrary, they seem to me to exclude such a reservation (1) by the world perfectum, (2) by the phrase per omnia nobis simliem absque peccato, and (3) by speaking of two wills and two operations," "Christ as Subject: A Reply", Collection: Papers by Bernard Lonergan, Collected Works of Bernard Lonergan, vol. 4 (Toronto: University of Toronto Press, 1988), 183. See also Lonergan, De Verbo Incarnato, $2^{\text {nd }}$ ed., (Rome: Gregorian University Press, 1961), 290ff.

${ }^{3}$ The Ontological and Psychological Constitution of Christ, Collected Works of Bernard Lonergan, vol. 7 (Toronto: University of Toronto Press, 2002), 178/179. The page numbers, separated by a virgule, designate the original Latin text and the English translation on the opposing page, respectively.

${ }^{4}$ A reformulation introduced in the third edition of De Verbo Incarnato (1964), 332; cited in Charles Hefling, “Lonergan on Christ's (Self-)Knowledge," Lonergan Workshop 20 (2008), 127-164 on 149.
} 
recognize his divinity without perceiving it as an element foreign to himself, that is, without risking a sort of self-induced schizophrenia? Lonergan tackles these difficulties head-on in The Ontological and Psychological Constitution of Christ. There he sets out to demonstrate that "Christ as man, through his human consciousness (conscientiam suam humanam) and his beatific knowledge (scientiam suam beatam) clearly understands (intelligit) and with certainty judges himself to be the natural Son of God and true God." $" 5$

Lonergan's demonstration rests on two bases: first, a translation of the Chalcedonian definitions into psychological categories; second, a nuanced rational psychology. Regarding the first, Lonergan links consciousness to nature; and he links a host of other categories — subject, "I," identity - to person. Accordingly, just as Christ, the one divine person, ontologically comprises two natures (divine and human), so does the one subject Christ psychologically comprise two consciousnesses (divine and human). ${ }^{6}$ This translation of Chalcedon has certain advantages, which will soon become apparent.

Regarding the second, Lonergan nuances the then-regnant rational psychology by adverting to a level "consciousness" prior to introspection (or reflexive knowledge). He dubs the former conscientia-experientia and the latter conscientia-perceptio. For Lonergan, conscientiaperceptio is basically the act of knowing oneself "as an object" (per modum obiecti) among other objects in the world. Just as I "know" my friend John, I also "know" myself. At this level, the modes of knowing are identical: the object just happens to be the subject in the case of introspection. It is only on the basis of the difference of objects, not on the basis of the manner

\footnotetext{
${ }^{5}$ Constitution of Christ, 204/205.

${ }^{6}$ In transposing the "metaphysical account of person and nature," Lonergan offers the following psychological reformulation of Chalcedon: "the person of Christ is an identity that eternally is subject of divine consciousness and in time became subject of a human consciousness." See "Christology Today: Methodological Reflections," A Third Collection, ed. Frederick E. Crowe, SJ (NewYork: Paulist, 1985), 74-99, on 91.
} 
of knowing, that knowledge and reflexive knowledge are "two kinds." Conscientia-experientia, on the other hand, which Lonergan considers "consciousness" in the strict sense, differs from reflexive knowledge inasmuch as it is a "preliminary unstructured awareness (notitia) of oneself and one's acts." In its most basic form, it is a "certain presence of oneself to oneself" (quaedam sui-praesentia-sibi). ${ }^{9}$ And the "self" rendered present through conscientia-experientia turns out to be a subject rather than a nature.

Having thus marked out distinct domains for conscientia-experientia and conscientiaperceptio, Lonergan can then unite them more fully as the subjective and objective poles of conscious acts. Lonergan explains that "what we experience interiorly ... is known to us neither by some special act nor as an object. In the very act of seeing a color I become aware not only of that color on the side of the object (ex parte obiecti) but also, on the side of the subject (ex parte subiecti) of both the one seeing and the act of seeing." 10 Consciousness does not make the subject known "as object" (per modum obiecti), but instead constitutes both "the subject in act and his act ... simultaneously and concomitantly with the knowledge of objects."11 Hence, conscientia-experientia does not refer to a particular cognitive act or even a particular object, but to the self-presence of the "I" throughout all human acts.

Lonergan challenges those who would deny this distinction with a clever reductio ad absurdum. He assumes that a cognitive act exercises no constitutive effect on its object. ${ }^{12}$ If consciousness is merely knowledge of an object, then it can reveal that object only "as it was in

\footnotetext{
7 "Consider, then, the two propositions, John knows his dog, John knows himself. In both, the subject is John. In the first, the object is John's dog. In the second, the object is John himself. It follows that knowing is of two kinds: there is direct knowing in which the object is not the subject; there is reflexive knowing in which the object is the subject," "Christ as Subject," 164.

${ }^{8}$ The Constitution of Christ, 164/165.

${ }^{9}$ Ibid., 186/187.

${ }^{10}$ Ibid., 158/159.

11 "Christ as Subject," 165.

${ }^{12}$ One wonders how Lonergan would have handled objections to this premise based on Heisenberg's uncertainty principle, which suggests that the observer affects the observed.
} 
its proper reality prior to the occurrence of the cognitive act or function named consciousness." 13

Absurdly, the conscious subject could then know itself only as if in a "pre-conscious" state:

If without consciousness John cannot possibly be the conscious subject of physical pain, then by consciousness John is merely manifested as being incapable of suffering. Similarly, if without consciousness John cannot be the consciously intelligent or the consciously rational or the consciously free or the consciously responsible principle of his own intelligent, rational, free or responsible acts, then by consciousness as knowledge of an object John merely knows himself as neither consciously intelligent, consciously rational, nor consciously free, nor consciously responsible. ${ }^{14}$

In other words, if consciousness were only reflexive knowing, the conscious subject would have only an external perspective on himself and his acts. He could not experience suffering or moral accountability directly. Without a deeper, fontal awareness, he could only infer them from an outsider's vantage.

Applying conscientia-experientia to the case of Christ's human knowledge turns out to have several advantages. First and foremost, it eliminates a tendency to posit an exaggerated psychological dichotomy in Christ. If the "I" belongs to person and consciousness belongs to nature, then there is in Christ one divine "I" experiencing himself ex parte subiecti through both divine and human consciousnesses. ${ }^{15}$ If the Word were present to Christ's human consciousness only ex parte obiecti, on the other hand, this would introduce a sort of unbridgeable chasm between the humanity and divinity of Christ. The human nature of Christ, conceived in this case almost as an autonomous "I," would gaze at Word from an infinite distance. The chasm could

\footnotetext{
13 "Christ as subject," 164.

${ }^{14}$ Ibid., 164-65.

${ }^{15}$ This is very close to the position of Fr. J. Galot, SJ, who suggests that the true question is not "how a man becomes conscious that he is the Son of God, but how the Son of God becomes humanly conscious of himself." Emphasis original. See Who is Christ?, 336-337. However, Galot does not make use of the self-presence of the divine subject in Christ's conscious acts, and must therefore bridge the gap between the subject and object of Christ's knowledge through recourse to "mystical filial knowledge." See op. cit., 339-343.
} 
not be spanned. ${ }^{16}$ And even if a tenuous bridge could be constructed, Christ's human "I" would then be obliged to turn toward the Word in awe and reverence. ${ }^{17}$ Yet, as Kereszty observes, "None of the New Testament writers ever presents Jesus as 'standing over against the Word' in adoration. The one over against whom Jesus stands in adoration and obedience is always the Father."18

By introducing conscientia-experientia, Lonergan better accounts for the biblical data. Rather than as two quasi-autonomous subjects, the incarnate Christ can be seen as a single divine "I" experiencing himself through a human consciousness. And finally, though Lonergan does not make this point, ${ }^{19}$ a Christ possessed of a single "I" would likely behave as the Christ depicted in the Gospels. That is, he would consecrate all his human faculties and energies to discerning and accomplishing the will of the Father rather than to self-reverence and selfcontemplation.

\section{Scientia Beata and Christ as Unique Comprehensor}

Naturally, some difficulties remain in explaining how Christ as man "clearly understands and judges with certainty" that he is the "natural Son of God and true God." For Lonergan, the traditional doctrine of the beatific vision still plays an important cognitive role-a role suggested

\footnotetext{
${ }^{16}$ For a brief discussion of the vulnerability of the positions of P. Galtier and P. Parente to this criticism, see Roch Kereszty, OCSO, "Psychological Subject and Consciousness in Christ," Communio 11:3 (1984), 258-277, on 26566.

${ }^{17}$ This seems to be Rahner's conclusion: "Now it may and indeed must of course be said that the doctrine of the unconfused and unchanged real human nature implies, as the struggle against monothelitism and the rejection of monophysitism shows, that the 'human nature' of the Logos possesses a genuine, spontaneous, free, spiritual, active centre, a human self-consciousness, which as creaturely faces the eternal Word in a genuinely human attitude of adoration, obedience, a most radical sense of creaturehood." See "Current Problems in Christology," Theological Investigations, vol. 1, trans. Cornelius Ernst, OP (New York: Seabury, 1961), 157-158.

Though Rahner also believes in consciousness as self-presence (das schlicthe Bei-sich-sein einer Seinswirklichkeit) rather than reflexive knowledge, he nonetheless seems to hold that consciousness makes the nature present to itself, not the subject. Therefore, Christ's two natures almost entail two "I"s. See ibid., 158 and the criticism by Kereszty in "Psychological Subject and Consciousness in Christ," 266-67.

18 "Psychological Subject and Consciousness in Christ," 267.

${ }^{19}$ Kereszty, however, does detect the resources to account for a more specifically filial consciousness in Lonergan's De Deo Trino, II. Pars systematica, where, according to Kereszty, Lonergan affirms the psychological circumincession of the immanent Trinity. See "Psychological Subject and Consciousness in Christ," 272.
} 
by Lonergan's preference for scientia over visio. According to Lonergan's epistemology, knowledge (scientia) that admits of clear and certain judgment belongs to "the side of the object." Experiential awareness (notitia), taken by itself, is vague, primitive, formal and belongs to "the side of the subject." Moreover, the fact that the divine person is the subject of Christ's human knowledge does not make his human knowledge special per se. As Charles Hefling clarifies, it is not the subject of knowing who makes knowing supernatural, but the object. ${ }^{20}$ Since consciousness is only an inchoate awareness from "the side of the subject," we still have to ask how Christ as man knows objectively that he is God.

For Lonergan, only the special assistance of the visio beata allows Christ the man to make this judgment. As he presents it, to "understand the quiddity of something is to know (cognoscere) that thing in its essence; and no created intellect can know God in his essence save through the beatific vision (per visionem beatam). ${ }^{21}$ Lonergan lists four conditions as "required and sufficient for this knowledge":

1) consciousness of himself

2) in which the subject (that which is aware of itself through consciousness) is the natural Son of God and himself true God;

3) a clear understanding of the quiddity of the natural Son of God and of the true God;

4) and a grasp of the identity between the conscious subject and the object thus quidditatively understood. ${ }^{22}$

Through the meeting of the Word as subject and the Word as object of Christ's human knowledge, Christ the man can judge that he is God.

\footnotetext{
20 "The object of seeing is color. Since colors are not God, seeing them is not supernatural. Nevertheless, if Christ the man saw colors, he saw them consciously. By seeing them he was aware of his seeing and-which is the point - aware of himself, seeing ... In the second place, to say that Christ, in performing any or all of the human acts he did perform, was conscious of himself is not to say that he knew himself. Consciousness alone is not selfknowledge, any more than sense-experience alone is knowledge properly so called," "Lonergan on Christ's (Self-)Knowledge," 141.

${ }^{21}$ Constitution of Christ, 216/217.

${ }^{22}$ Ibid., 214/215.
} 
Lonergan claims that condition 4) obtains "immediately" (statim) upon the conjunction of the other three. This has consequences that seem unattractive at first glance. Since condition 2) is an ontological condition and since condition 3), the beatific vision, does not admit of degrees, it seems that Christ will judge that he is God as soon condition 1) is met, that is, as soon as Christ becomes conscious of himself as subject. However, since self-presence in Lonergan's stipulative sense is a feature of even basic psychological operations, Christ could have so judged from the dawn of his self-awareness. ${ }^{23}$ Hence, Christ's knowledge of his divinity does not seem to admit of growth and development.

With the "I" of the Word present to Christ the man on "the side of the subject," and scientia beata available to Christ the man on "the side of the object," Lonergan can point to an appreciable uniqueness in Christ's human consciousness and knowledge. Indeed, Christ emerges as perfect comprehensor, somehow aware- even from his earliest days - that he is Son of God and true God. Such cognitive advantages would doubtlessly qualify Him as a uniquely trustworthy raconteur of the things of God, and Christians could take comfort in this. On the other hand, the image is also discomfiting, since it seems to differentiate Christ's inner world so sharply from the rest of humanity. Is there any room, then, for Christ to be a "wayfarer" like us, the subject of a normal human development?

\section{Scientia Ineffabilis and Christ as Viator}

Lonergan can, in fact, robustly affirm Christ's "normal” human development, but only in the third edition of his Christology "textbook," De Verbo Incarnato, does he complete the groundwork requisite for this affirmation. There Lonergan provides a helpful clue as to the true nature of the scientia beata by situating it in an elaborate thesis on Christ's earthly psychology:

\footnotetext{
${ }^{23}$ Hefling, "Lonergan on Christ's (Self-)Knowledge,” 143-44.
} 
In his earthly life, Christ had both effable and ineffable human knowledge as well as his divine knowledge. As a beholder, he knew God immediately, by the ineffable knowledge that is also called beatific. In the same act, but mediately, he knew everything else that pertained to his work. As a pilgrim, however, he elicited by effable knowledge the cognitional acts, natural and supernatural, that constituted his human, historical life. ${ }^{24}$

Notably, the formula "beatific vision" receives a second makeover in this thesis. In Constitution of Christ, Lonergan had already replaced "vision" with "knowledge," and by the third edition of De Verbo Incarnato he replaced "beatific" with "ineffable." Hefling sees three advantages to this shift from "beatific vision" to "ineffable knowledge." First, it replaces the "ocular metaphor" of vision with an act of intellection. Second, it does not give the misleading impression that such knowledge excludes suffering, as the adjective beata does. ${ }^{25}$ Third, it highlights the revelatory purpose of Christ's cognitive privilege: namely, uttering the unutterable. This point was notably missing in Constitution of Christ, a supplemental text dedicated to the narrower question of Christ's self-understanding. ${ }^{26}$

This complex thesis wants some unpacking. Apropos of the normalcy of Christ's human knowledge, it is worth mentioning 1) that Lonergan equates the beatific vision to ineffable, supernatural knowledge and 2) that he means "ineffable" sensu stricto. Both Christ's immediate knowledge of the Trinity and his knowledge mediated "in the Word" are beyond conceptualization and verbalization. Knowledge "in the Word" is knowledge of finite realities, but stripped of "multiplicity or sequence," or anything else "empirically residual."27 Such "dematerialized" knowledge is inexpressible — even to oneself. Christ does not, therefore, "see" a

\footnotetext{
${ }^{24}$ De Verbo Incarnato, $3^{\text {rd }}$ ed., 332; cited in Hefling, “Lonergan on Christ's (Self-)Knowledge," 149. Emphasis mine. For Hefling's mapping of these four major distinctions (comprehensor/viator, effable/ineffable, immediate/mediated, and supernatural/natural) onto the four "layers" of Christ's human knowledge, see Table 1 at the end of the paper.

${ }^{25}$ For Lonergan, beata has become a sort of term of art, which does not convey psychological contentment as much as "knowing God essentially" (cognoscere Deum per essentiam). See De Verbo Incarnato, $2^{\text {nd }}$ ed., 334.

${ }^{26}$ Hefling notes that Lonergan was then teaching from Constitution of Christ, an already existing Christology textbook, penned by Lonergan's dissertation director, Fr. C. Boyer, SJ. See "Lonergan on Christ's (Self-)Knowledge," 129.

${ }^{27}$ Hefling, "Lonergan on Christ's (Self-)Knowledge," 152.
} 
detailed trajectory of his life. He does not number his steps to Jerusalem to ensure that they square with some divinely-foreordained total.

Nevertheless, ineffable knowledge is not without consequence. It profoundly informs Jesus's words and deeds — whose goal seems to have been rendering the ineffable effable. And, though Lonergan denies that we can conceptualize Christ's scientia ineffabilis, he does think we can draw helpful analogies. First, he conjures up the image of a professor who knows Aquinas' Summa Theologiae so well that he can envision it almost as a simple, intuitive whole. This professor then conceives the project of making the Summa into a movie. He knows "in its entirety what has to be represented, yet the entirety of how to represent it remains to be discovered." ${ }^{28}$ Christ likewise knows "ineffably" the mystery of God, but would nonetheless discover how best to render it "effable" over the course of a human life. Second, Lonergan compares ineffable knowledge to the "light of the intellect," by which he means simultaneously the metabolism and the hunger of the human intellect. Like ineffable knowledge, this intellectual light is in some way primitive and ineffable, that is, devoid of facts, concepts and pictures; nonetheless, it radically determines the shape of our intellectual lives. For Lonergan, ineffable knowledge shapes Christ's human intellect as deeply as the "light of the intellect" does ours.

Of course, both analogies limp. The first analogy limps because even the professor's intuitive grasp of the Summa, inasmuch as it is derived from printed pages, Latin words, and sequential arguments, remains residually empirical. He only translates from one empirical medium (the Summa) to another (film). The point, however, is that Christ may truly "learn" (Heb 5:8) how best to express a God-already-known, just as an eminent Thomist may learn filmmaking to express a vision-already-grasped. The second analogy limps in a different way. Though the intellectual "light" is not residually empirical, it falls short by virtue of its

\footnotetext{
${ }^{28}$ De Verbo Incarnato, $3^{\text {rd }}$ ed., 343; cited in Hefling, "Lonergan on Christ's (Self-)Knowledge," 157.
} 
directionality. Whereas the "light" impels non-divine persons towards God as the end and adequate term of the intellect, Christ's ineffable knowledge impels him from God toward us: "Christ the man diffused goodness from an end achieved, beheld, and loved." 29 The value of the analogy, however, lies in its suggestion that Christ's desire to reveal God was as ubiquitous and constitutive of his human psychology as the intellectual light is of ours. ${ }^{30}$

In sum, Lonergan's Christology is a solid achievement. He provides both the phenomenology of consciousness and the "translation" of Chalcedon necessary for overcoming psychological dualism in Christ. This allows for the extraversion of Christ's consciousness toward the Father, even if Lonergan does not draw this conclusion himself. By defending Christ's ineffable knowledge, Lonergan substantiates Christ's status as unique comprehensor; and by dispelling confusion about the true nature of ineffable knowledge, Lonergan still gives real meaning to Christ's status as viator In this way he defuses the soteriological concern that Christ be "like us," while securing the minimal requirements for the possibility of revelation.

\section{Balthasar and Christ's "Mission Consciousness"}

Hans Urs von Balthasar shows considerable agreement with Lonergan on our three guiding points - though the extent of their agreement is not immediately apparent. Indeed, in the third volume of his Theo-Drama, the Balthasar generally prefers the "dramatic" $"$ formulation of "mission-consciousness" to the scholastic language of "beatific vision." And when he does bring up the beatific vision, he denies — albeit in a rather nuanced way — that Christ enjoyed it perpetually. At the same time, mission-consciousness does affirm that there is no gap between

\footnotetext{
${ }^{29}$ De Verbo Incarnato, $3^{\text {rd }}$ ed., 406; cited in Hefling, "Lonergan on Christ's (Self-)Knowledge," 157.

${ }^{30}$ I am generally indebted to Hefling's lucid discussion of these analogies in ibid., 155-58.

${ }^{31}$ For an elaboration of Balthasar's "dramatic" theology that distinguishes it both from post-liberal "narrative theology" and from Lonergan's "theoretical" theology, see Randall Rosenberg, "Theory and Drama in Lonergan's and Balthasar's Theology of Christ's Consciousness and Knowledge," (Ph.D. diss., Boston College, 2008), 40-43.
} 
Christ's person and mission. ${ }^{32}$ Balthasar brings together both the denial and affirmation when he states that:

we can most definitely hold fast to the idea that Jesus knew of his identity as the Son of God right from the start - as his unique relationship to his "Abba, Father" adequately shows - while acknowledging that the awareness of this identity only came to him through his mission, communicated by the Spirit. This would exclude the "beatific vision" of God, at least for periods. ${ }^{33}$

This important summary already hints at the agreement between Balthasar's "mission consciousness" and Lonergan's "ineffable knowledge” on our three thematic points—namely, 1) that Christ's human consciousness was directed primarily to the Father rather than the Word, 2) that Christ was - "right from the start"-a unique comprehensor, and 3) that Christ was nonetheless a viator in solidarity with the human condition. There is disagreement about the constancy with which Christ enjoyed the beatific vision, but one that turns mostly on different understandings of the term.

\section{Psychological Unity through Mission Consciousness}

As Balthasar makes clear in the passage above, the fact that Jesus "knew his identity as the Son of God" does not mean that he stood reverentially before the Word, but that he stood obediently before his "Abba, Father." In order to responsibly affirm both these features of Christ's psychology, one must furnish two explanations: first, one must explain the principle of Christ's psychological unity; second, one must explain the orientation of this unified psyche

\footnotetext{
${ }^{32}$ The Dramatis Personae: The Person in Christ, Theo-Drama vol. 3, trans. Graham Harrison (San Francisco: Ignatius Press, 1992), 167. Hereafter abbreviated TD 3. According to Aidan Nichols, OP, the coincidence of mission and identity gets at the heart of Balthasar's dramatic theology. For in the "identity of Christ's person and mission we have the realization par excellence of what is meant by a dramatic character: a figure who by carrying out his own rôle attains or discloses his true human face," No Bloodless Myth (Washington, DC: CUA Press, 200), 103.

${ }^{33}$ TD 3, 195.
} 
toward the Father. Whereas Lonergan focuses on the first explanation, Balthasar attempts both in the "fundamental paradox of [Christ's] self-consciousness and mission-consciousness." 34

Summarily stated, Balthasar considers Christ's mission-consciousness to be the economic manifestation, in the human psyche of Christ, of the intra-trinitarian relations. Balthasar asserts repeatedly that missio is simply the economic form of processio. ${ }^{35}$ Since the Trinitarian persons are subsistent relations, and since relations_-even subsistent ones_-require a terminus a quo and a terminus ad quem, it is fitting that Christ's "I" have an inner dynamism. Jesus' consciousness is bi-focal: "The 'I' of Jesus also radiates the 'I' of the Father with which it is united."36 "He is the "one sent.",37 Hence, one might say that Christ knows his divine identity, but that this identity is ultimately transparent to the Father. For to know oneself as Son is necessarily to know oneself as generated by the Father.

Balthasar further clarifies his paradoxical position when he referees a theological debate between K. Rahner and H. Riedlinger. ${ }^{38}$ On Balthasar's reading, Rahner holds that Christ possesses a visio immediata of God, which Rahner describes as the equivalence between Jesus' “simple presence to himself" and his "original, non-objective consciousness of the Son of God." Balthasar then notes two objections that Riedlinger raises against this position. First, Jesus' consciousness of divinity does not seem to refer primarily to his own divinity but to the Father's. Second, such an affirmation would entail a "permanent, suprahistorical radiance over and above his basic human constitution." This is obviously problematic for Riedlinger. ${ }^{39}$

\footnotetext{
${ }^{34}$ Ibid., 167.

${ }^{35}$ Ibid., 154, 173, 201.

${ }^{36}$ Ibid., 169.

${ }^{37}$ Ibid., 166.

${ }^{38}$ Balthasar is here referring to Rahner's aforementioned essay "Dogmatic Reflections on the Knowledge and SelfConsciousness of Christ," as well as to Riedlinger's Geschichtlichkeit und Vollendung des Wissens Christi, Series Quaestiones Disputatae 32 (Herder 1966), esp. 148-53.

${ }^{39}$ Citations for this paragraph taken from TD 3, 172-73.
} 
Balthasar thinks both theologians make legitimate points-points he thinks he can accommodate better in his notion of mission consciousness. With Rahner, he affirms that Chist's "self-consciousness and God-consciousness coincide." $"$ With Riedlinger, Balthasar concurs that the "direct relationship with the Father must show itself in [Christ's] consciousness of mission."41 Balthasar's solution of a bi-focal mission-consciousness allows him to hold both, since Christ's knowledge of himself as Word already includes the knowledge of his generation ex Patre. Balthasar, moreover, accepts what Riedlinger finds problematic: Christ does indeed manifest a "permanent, supra-historical radiance." For Christ "does not reveal the Father merely from time to time; he reveals him in every situation in his life." ${ }^{42}$ Excepting specification of the Father, Balthasar's words approach Lonergan's affirmation that "Christ the man diffused goodness from an end achieved, beheld, and loved."

\section{Christ as Unique Comprehensor}

From what has been said so far, we may infer that Balthasar does not consider the beatific vision a necessary condition for radiating the Father. Balthasar maintains that Christ revealed the Father "in every situation in his life" while also claiming that Christ enjoyed the beatific vision only intermittently. "Mission-consciousness" is sufficient to ground Christ's “suprahistorical radiance." Here Balthasar parts company with Lonergan, who sees scientia beata as the condition for the possibility of revelation. As we shall see below, however, this ostensible disagreement owes much to Balthasar's hyper-literal understanding of the "beatific vision." What Balthasar actually affirms of Christ comes close to what Lonergan affirms in Christ's “ineffable knowledge."

\footnotetext{
${ }^{40}$ Ibid., 173.

${ }^{41}$ Ibid., 173.

42 Ibid., 173.

${ }^{43}$ De Verbo Incarnato, $3^{\text {rd }}$ ed., 406; cited in Hefling, “Lonergan on Christ's (Self-)Knowledge," 157.
} 
Despite his reservations about the beatific vision, Balthasar depicts Christ, in substance, as a qualitatively unique comprehensor. He acknowledges that the theological tradition that would ascribe to Christ "everything knowable to man" is "long," "serious," and "solidly based on a biblical theme." ${ }^{44}$ Hence, he tries to do justice to its perennial insights in his presentation of Christ's mission consciousness. For Balthasar, the latter always contains two features: a "relationship to the one who sends" (explored above), as well as "mission's future prospect."45 Regarding the first, Balthasar considers Christ's conscious relationship to the Father "absolute"46: "The task given him by the Father, that is, that of expressing God's Fatherhood through his entire being, through his life and death in and for the world, totally occupies his selfconsciousness and fills it to the brim." ${ }^{47}$ In fact, though Balthasar doubts Christ's constant enjoyment of visio beata, he does allow Christ visio immediata - provided the field of “immediate vision" be limited to Christ's mission:

Jesus is aware of an element of the divine in his innermost, indivisible selfconsciousness; it is intuitive insofar as it is inseparable from the intuition of his missionconsciousness, but it is defined and limited by this same mission-consciousness. It is of this, and of this alone, that he has a visio immediata, and we have no reason to suggest that this visio of the divine is supplemented by another, as it were, purely theoretical content, over and above his mission. ${ }^{48}$

Balthasar, in short, wants to maintain that Christ's divinity suffused his self-consciousness and, at the same time, to exclude the impression that Christ had the missing proof of Fermat's Last Theorem ready-to-hand.

Regarding "mission's future prospect," Balthasar reasons that Christ must have understood his mission as one of extending universal salvation. Since a "more-than-human

\footnotetext{
${ }^{44}$ TD 3, 173-74.

45 Ibid., 168.

46 This is an adjective that Balthasar applies to Christ's consciousness on several occasions, but without definition or exploration. For a critical evaluation of this language, see Rosenberg, "Theory and Drama," $78 \mathrm{ff}$.

${ }^{47}$ TD 3, 172 .

${ }^{48}$ Ibid., 166.
} 
mission - to reconcile the world with God — cannot be a secondary and accidental development of human consciousness," Christ must have always been "adequately aware of its universality.",49 He cannot have simply "deduced" it from external observation. Similarly, with respect to the sinners, Balthasar takes exception to the assertion of Mystici Corporis that Christ "had from the outset the explicit knowledge possessed by all his 'members." ${ }^{50}$ Nonetheless, he does affirm that Christ evinces a "certain readiness to be affected by the inner constitution of his fellow men ... in such a way that, in principle, the entire temporal and eternal destiny of any and every other person comes to lodge within his own sphere."51 Hence, though Balthasar remains rather imprecise throughout, he does acknowledge that Christ detected in himself a "more-than-human mission" of universal dimensions. ${ }^{52}$

Finally, Balthasar feels that a "mission consciousness," by virtue of its receptivity to the Father, opens up the possibility of a certain modulation of what Lonergan would call supernatural, effable knowledge. Balthasar, for example, grants that Christ may have been given a special, prophetic gift for reading human hearts "in each particular situation." ${ }^{53}$ Similarly, Christ's mission may call for

the prophet's detailed prospect of the world's entire situation and its relation to God, or of individual events of the present, the past or the future; or he may have an intuition of these things. So too his field of attention may be restricted, for obedience's sake, to a

\footnotetext{
${ }^{49}$ Ibid., 166.

${ }^{50}$ Ibid., 178.

${ }^{51}$ Ibid. Emphasis original.

${ }^{52}$ Balthasar emphasizes the singularity of Christ's inner-experience and mission especially in relation to his passion. He claims in Mysterium Paschale that the "redeeming act consists in a wholly unique bearing of the total sin of the world by the Father's wholly unique Son, whose Godmanhood (which is more than the 'highest case' of a transcendental anthropology) is alone capable of such an office," Mysterium Paschale, trans. Aidan Nichols, OP (San Francisco: Ignatius Press, 2000), 137-38.

Elsewhere he claims the uniqueness of Christ's on the basis of his unique openness to rest of humanity and the Father: "Again, it is unthinkable that people following Christ should have had to go through more terrible experiences than their Lord himself; their experiences can only be a muted echo of the unique and incomparable burden which the God-Man endured," Does Jesus Know Us? Do We Know Him?, trans. Graham Harrison (San Francisco: Ignatius Press, 1983), 38.

${ }^{53}$ TD 3, 178 .
} 
particular horizon, as in a narrow ravine: the flow of his mission is contracted as it pushes its way through. ${ }^{54}$

Hence, Balthasar does not object in principle to Christ's divine self-knowledge or his deployment of more-than-human knowledge. He objects only to those who would imagine Christ's “field of attention" dominated, for perfection's sake, by a sort of inert and propositional omniscience.

Balthasar clearly affirms the uniqueness of Christ's consciousness, and thus does not deny Christ certain spiritual and psychological advantages over humanity in general. He does, however, distinguish between visio beata and visio immediata, denying Christ's constant enjoyment of the former. Moreover, he admits this visio immediata only inasmuch as it provides data pertinent to Christ's mission. At least terminologically, then, Balthasar qualifies Christ's status as comprehensor in significant ways vis-à-vis Lonergan and the scholastic tradition. However, these verbal reservations may stem more from a simplistic understanding of the traditional terms than from substantial differences of theological judgment.

\section{Christ as Viator in Solidarity}

Though Balthasar never defines what he means by vision, one may gather from textual clues that he is somewhat influenced by the ocular metaphor. For example, after concluding that the Spirit's mediation of Christ's mission would “exclude the 'beatific vision' of God, at least for periods," he clarifies his position in a footnote, where he quotes J. Guillet on the scene of Christ's baptism: "It is not said that Jesus, with his human eyes, saw the Father, but only that he saw the heavens opened and the Spirit descending upon him." 55 Though Balthasar does not understand physical eyes here, he does seem to object to the general picture of Christ's casually indulging in "effable" visions of the Father and the Spirit. Most often, however, Balthasar seems

\footnotetext{
${ }^{54}$ Ibid., 197.

${ }^{55}$ Ibid., 195, fn. 55. Emphasis mine.
} 
to understand visio beata as a sort of discursive omniscience. He at least implies this

understanding when he objects to Christ's holding all knowledge in "his field of attention," or to his entertaining some "purely theoretical content" for perfection's sake. Understanding the beatific vision in this way, Balthasar naturally considers it a threat rather than an aid to normal human functioning. Hence, he would rather dispense with the term than join the long list of theologians who - while holding onto the formula — have nevertheless felt compelled to banish "direct vision" to the "upper regions" of the psyche, lest it "endanger the life of his normal human soul.",56

With regard to the "future prospect" of Christ's mission, Balthasar objects specifically to discursive omniscience because he considers misleading any "pious picture [that] shows the little Child playing with pieces of wood in the form of a cross." ${ }^{, 57}$ In other words, Christ's life is not a performance choreographed in advance. Rather, freedom and obedience coincide in Christ's mission-consciousness. He must carry out this mission by testing, planning, and consideringby genuinely "human energies." 58

Above all, Balthasar winces at St. Thomas' conclusion that Christ's beatific vision would preclude his learning from non-divine persons. For Balthasar, denying this human influence would compromise the integrity of the Incarnation, for it is the very nature of a human "I" to be awakened by a "Thou." "59 The "Thou" that wakes Christ's "I" is above all Mary, who forms Christ's mission-consciousness, not just "from the outside," but in a sort of "pre-

\footnotetext{
${ }^{56}$ Ibid., 196.

${ }^{57}$ Ibid., 173.

${ }^{58}$ Ibid., 168.

${ }^{59}$ Ibid., 175. Balthasar remarks: "Here the Scholastic a priori comes up against an elementary truth of human nature: unless a child is awakened to I-consciousness through the instrumentality of a Thou, it cannot become a human child at all. Thomas' proposition is at odds with the logic of the Incarnation."
} 
established harmony" with the "specific nature of his self-consciousness."60 Balthasar adds the mission and death of John the Baptist, which doubtlessly "served as a sign to Jesus that he should begin his public ministry.",61 It is important for Balthasar that the "Father's will is encountered in history no less than in interior inspiration."62 The human mediation of Christ's mission thus becomes a necessary condition for Christ's status as viator and for his genuine solidarity with us.

Like Lonergan, Balthasar provides a "natural analogy" for Christ's missionconsciousness. Accordingly, Christ relates to his mission like Mozart does to the Magic Flute, which Balthasar considers an "inspired" work "in all its parts." 63 Mozart, like any artist, is most "free," not when he is hesitating between artistic possibilities, but when he "is 'possessed' by the true 'idea' that presents itself to him in finite form and [he] follows its sovereign commands.",64 The "quite contrary styles" of the Magic Flute are "evidence of the highest possible playfulness and freedom, yet all of them are bound together by [Mozart's] unmistakable personality to form the most natural unity." 65 Balthasar's point seems to be that, despite the ebb and flow of Christ's earthly share in the divine prerogatives, Christ's filial mission — the "true 'idea' that presents itself"-nevertheless encompasses all the moments of his life and impresses upon them the splendor of the Father. It is in surrendering to this missionary "idea" that Christ exercises the highest "artistic" freedom and human inventiveness. ${ }^{66}$ Balthasar's analogy turns out to be more

\footnotetext{
${ }^{60}$ Ibid., 176. Lonergan would surely agree that Mary had some role in awakening Christ's human personalityonce the proper distinctions were made. Balthasar seems to share Rahner's equation of "I" and "consciousness," which Lonergan is at pains to disambiguate. Lonergan would perhaps say that Mary awakens Christ's human consciousness, but not his "I", which is constituted instead by relationship to the Father.

${ }^{61}$ Ibid., 178.

${ }^{62}$ Ibid.

${ }^{63}$ Ibid., 198.

${ }^{64}$ Ibid.

${ }^{65}$ Ibid.

${ }^{66}$ Ibid. Balthasar interprets himself as follows: "What this analogy teaches us is this: when Jesus lays hold of his mission and fashions it, he is not obeying some alien power. The Holy Spirit who inspires him is not only the Spirit of the Father (with whom the Son is 'one') but also his own Spirit... It may be that he lives for it and for its own sake (the inspired artist can experience something analogous), but he will not able to say that his mission existed (in
} 
suited to evoking the paradox of obeying-freedom than the paradox of learning-omniscience, but it contains both aspects.

\section{Conclusion: Compatibility and Complementarity}

In all three concerns - in Christ's orientation to the Father, in Christ's unique and comprehensive human knowledge, and in Christ's unfeigned learning and discernmentLonergan and Balthasar show compatible and complementary views. Regarding Christ's filial consciousness, Lonergan and Balthasar agree that Christ did not comprise two psychological subjects and, hence, did not orient himself qua human toward the Word. Lonergan provides the foundation for this by relating subject to person and consciousness to nature. He can thus describe the Word as experiencing himself (ex parte subiecti) through the human consciousness of Jesus. The Word is both the subject of Christ's human knowing and its "ineffable" object. In a similar way, Balthasar - though imprecise and inconsistent in his psychological terms — takes pains to present Christ as a unified and extraverted subject. Since missio is but the economic translation of the immanent processio, Christ always experiences himself as generated ex Patre.

Moreover, even the diverse approaches of these two theologians turn out to be mutually enriching. Whereas Lonergan contributes the fine distinctions necessary for eschewing psychological dualism, he does not explain how Christ's consciousness reflects the actus notionalis of the Word - namely, the Son's generation from the Father. Balthasar, on the other hand, sketches a psychology more proper to the Word, one which contains an inherent reference to the Father mediated by the Spirit. ${ }^{67}$

some eternal time) prior to his having affirmed and grasped it; for it is always his... he must fashion it out of himself in utter freedom and responsibility; indeed, in a sense, he even has to invent it."

${ }^{67}$ Kereszty criticizes Lonergan on this score: "Lonergan does affirm this psychological circumincession of the divine persons in the immanent Trinity but fails to draw the necessary conclusions for the psychological subject of the incarnate Son. He treats the latter as one of the divine persons who has become incarnate rather than as the incarnate Son. In his system it seems to me, any of the divine persons could be substituted for the Son" "Psychological Subject and Consciousness in Christ", 272. 
Regarding Christ's unique spiritual privileges and his status as comprehensor, Balthasar and Lonergan are in basic agreement that Christ is perpetually revelatory. For Lonergan, Christ's static and uninterrupted enjoyment of scientia beata or scientia ineffabilis is the necessary condition of revelation. Christ's whole life makes the unspeakable speakable. Lonergan's position here is roughly equivalent to Balthasar's insistence that the Son reveals the Father always — not only "from time to time." Moreover, when Balthasar qualifies Christ's knowledge, rejecting the visio beata but affirming a certain visio immediata of his mission, he does so for the same reasons that Lonergan shifted from visio beata to scientia beata to scientia ineffabilis. Both theologians want to avoid the picture of Christ's mechanical obedience to a history minutely scripted by the Father. Hence, when Balthasar demurs on Christ's theoretical omniscience, he objects not to Christ's ineffable knowledge of historical events "in the Word," but to the a priori attribution of this knowledge to Him in a discursive mode, as if it were everpresent to his "field of attention."

Despite their basic agreement, their approaches are distinct enough to prove complementary. Lonergan, for his part, helps to break the grip of the ocular metaphor, both by carefully distinguishing among the layers of Christ's human knowledge and by re-describing the beatific vision as "ineffable knowledge." Balthasar, for his part, suggests the historical "trigger" by which this fund of ineffable knowledge is reduced to empirical, sequential, and verbal knowledge. This trigger would be the emergent requirements of Christ's mission. Christ would receive even his knowledge in obedience to the mission given Him by the Father, a knowledge which he would deploy according to the demands of contingent circumstances.

Finally, the analogies that each theologian employs describe Christ's life as a paradox of learning to express the already-known. Thereby, they secure Christ's status as genuine viator. 
The notable absence in Balthasar of any non-empirical analogy, such as Lonergan's "light of the intellect," hints that Balthasar never quite abandoned thinking of the "beatific vision" discursively. Nonetheless, the artistic analogies_-Lonergan's example of an eminent Thomist producing a film or Balthasar's example of Mozart composing the Magic Flute — give convergent descriptions of Christ's work. For Lonergan, Christ learns to express the changeless mystery of the Father through the vicissitudes of his historical life, gathering a constellation of images and narratives into which he can pour his single, luminous insight. Balthasar describes Christ's creative expression of the Father similarly and with an emphasis on freedom. Moreover, Balthasar complements Lonergan by highlighting Christ's freedom by and attending specifically to Mary's role in awakening Christ's human consciousness. He thus supplements Lonergan's exposition with the insights of Mariology and Christian personalism. ${ }^{68}$

It might still be objected that any epistemic privilege — whether ineffable knowledge or mission-consciousness - estranges Christ from us. We can no longer take comfort in his life since Christ is no longer "like us in all things but sin." However, while Chalcedon did claim that Christ had all the attributes that we have (except $\sin$ ), Chalcedon did not seem to claim that we have all the attributes that Christ had. We cannot both insist that Christ brought a novum into the world and deny that Christ has any special gifts or privileges. Moreover, one might argue that something like scientia beata or mission-consciousness is a necessary condition for revelation. If the ineffable did not somehow lodge in Christ's human sphere, then we have no secure basis for thinking that we have seen the "image of the invisible God" (Col 1:15).

Despite obvious differences in style and formulation, Lonergan and Balthasar paint the same portrait of Christ's consciousness and human knowledge. Christ's consciousness is

\footnotetext{
${ }^{68}$ Kereszty suggests that Balthasar may complement Lonergan by drawing out the "dialogical nature of subject and consciousness," which includes religious experiences "mediated by human encounter," "Psychological subject and consciousness in Christ," 270-72.
} 
transparent to the Father. Christ is also simultaneously comprehensor and viator, since his human psychology is profoundly marked by both human and "more-than-human" sources of knowledge. Christ is both free and obedient, both nescient and knowing, both unique and "like us in all things." In sum, Christ emerges as the artisan of revelation, the single creative figure who has made "all things new" (Rev. 21:5). 
Table 1: The "Layers" of Christ's Human Knowledge ${ }^{69}$

\begin{tabular}{|c|c|c|c|c|}
\hline $\begin{array}{l}\text { Viator/ } \\
\text { Comprehensor }\end{array}$ & $\begin{array}{l}\text { Effablel } \\
\text { Ineffable }\end{array}$ & Layers of Knowing & $\begin{array}{l}\text { Immediatel } \\
\text { Mediated }\end{array}$ & $\begin{array}{l}\text { Supernatural/ } \\
\text { Natural }\end{array}$ \\
\hline \multirow{2}{*}{$\begin{array}{l}\text { Eternal Life as } \\
\text { Comprehensor } \\
\rightarrow\end{array}$} & \multirow{2}{*}{$\begin{array}{l}\text { Ineffable } \\
\text { Knowledge, } \\
\text { i.e., } \\
\text { "beatific } \\
\text { vision" } \\
\rightarrow\end{array}$} & Immediate, e.g., Trinity & $\begin{array}{l}\text { Immediate } \\
\leftarrow\end{array}$ & \multirow{3}{*}{$\begin{array}{l}\text { Supernatural } \\
\leftarrow\end{array}$} \\
\hline & & $\begin{array}{l}\text { Mediated "in the Word", } \\
\text { e.g., Incarnation; all that } \\
\text { pertained to Christ's work }\end{array}$ & \multirow{3}{*}{$\begin{array}{l}\text { Mediated } \\
\leftarrow\end{array}$} & \\
\hline \multirow{2}{*}{$\begin{array}{l}\text { Human, } \\
\text { Historical Life } \\
\text { as Viator } \\
\rightarrow\end{array}$} & \multirow{2}{*}{$\begin{array}{l}\text { Effable } \\
\text { Knowledge } \\
\rightarrow\end{array}$} & $\begin{array}{l}\text { Supernatural } \\
\text { yet Effable }\end{array}$ & & \\
\hline & & Natural and Effable & & $\begin{array}{l}\text { Natural } \\
\leftarrow\end{array}$ \\
\hline
\end{tabular}

${ }^{69}$ Adapted from the chart provided by Hefling in "Lonergan on Christ's (Self-)Knowledge," 150. 